\title{
The Effect of Self-Confidence Moderation on the Effect of Emotional Intelligence on Employee Work Stress at PT. Orange Indonesia Mandiri Medan
}

\author{
Ahmad Fadli ${ }^{1}$, Amin Hou ${ }^{2}$, Roni Juliansyah ${ }^{3}$, Debora Tambunan ${ }^{4}$ \\ 1,2,3,4 STIE Mahkota Tricom Unggul, Indonesia \\ haqimdanyara@yahoo.co.id
}

\begin{abstract}
The purpose of this study is to determine the effect of emotional intelligence on work stress and to determine the effect of emotional intelligence on work stress through self-confidence. This research was conducted at PT. Orange Indonesia Mandiri Medan by selecting 55 employees as respondents. Furthermore, data collection used a questionnaire with path analysis in proving the research hypothesis. The results showed that emotional intelligence had no positive and significant effect on work stress and emotional intelligence had no positive and significant effect on work stress through self-confidence. This means that when emotional intelligence and self-confidence are getting better, it will reduce employee work stress.
\end{abstract}

Keywords

intelligence; confidence; workstress

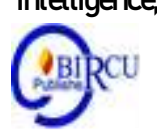

\section{Introduction}

The success key of a company will be largely determined by the quality of its human resources. Good equipment will greatly support the work of employees (Sahrah, 2019). A developed company will treat every employee as a company asset that must be managed properly (Martin, 2020). For this reason, companies should invest in building a solid foundation to support the company's survival in the future (Fajrin, 2018). Every company basically wants to have human resources or employees who are able to work very well. But in fact, each employee has different characteristics (Chaniago, 2018). Furthermore, the resources owned by the company will be positioned to fill existing positions in the company. Every employee certainly faces a workload. A heavy workload will make employees feel stressful at work. Work stress is a stressful condition that creates a physical and psychological imbalance that affects the emotions, thought processes, and conditions of an employee (Rivai, 2014).

The work stress experienced by each employee will have a bad impact on the completion of their work. In minimizing these problems, the company will strive for the capabilities of employees in the position they accept (Rahmat, 2017). Employees who have good emotional intelligence tend to be able to face all the challenges and problems they face. Employees will know how to behave with other employees when there is a problem they are facing. Emotional control will provide clear thinking in taking every step and decision.

Emotional intelligence will also affect an employee's confidence in building communication relationships with colleagues (Anwar, 2011). The confidence of an employee is obtained through work experience or from internal factors of an employee. Employees with confidence will not hesitate in deciding every step of action they should take (Handayani, 2014). Self-confidence will also emerge with guidance and direction 
from a leader. Employees will continue to learn and imitate how their superiors take quick action in providing solutions to their work problems.

The main problem in this research is that there are still many employees who have not been able to complete their tasks according to the expected grace period. Employees often feel that the time given to complete a job too fast is not proportional to the availability of the number of human resources. This causes some employees to feel bored and stress about their work targets.

One of the factors that are considered to influence job stress is the emotional intelligence possessed by each employee. Often times the result of a workload that takes a short time coupled with the inability of an employee to control his emotions can lead to increased stress at work. In addition, not all of these employees are born with different genetics. So that not all employees will be able to accept every change in the company.

Self-confidence is also considered to have an influence in reducing boredom at work. Making quick and correct decisions greatly reduces boredom at work. However, fast and precise will have clear benchmarks. Often decisions that take too long will require a deep level of analysis to determine what decision to make.

This research is very important for PT. Orange Indonesia Mandiri Medan to see the extent to which work stress is influenced by emotional intelligence through the sense of selfconfidence possessed by employees. So that it is expected to provide tangible benefits to continue to minimize work stress faced by each employee.

\section{Review of Literatures}

\subsection{Emotional Intelligence}

The ability is to be able to control their emotions in facing problems or making relationships between other employees. Employees must also be skilled at self-awareness, self-control, and motivation to get empathy from the people around them (Goleman, 2015). Motivation is an encouragement that makes people want to work or act in a certain way.Speaking of motivational matters, what is discussed is human needs (Ningsih, 2018). Emotional intelligence can also be used to manage emotional levels according to the abilities of an employee in order to achieve his career to become a better person (Wibowo, 2014). Employees who are able to manage their emotions will have the ability to minimize work stress (Aprillia, 2019). Furthermore, an employee's emotional intelligence is influenced by factors that are genetic in nature. Employees can have good emotional intelligence if they are hereditary elements. It is only natural that it will continue in the future generations. Next, the factors that make employees have emotional intelligence are their environment. A supportive environment in forming a lifestyle and becoming a habit that lasts for a long time tends to make an employee behave in accordance with existing conditions (Goleman, 2015).

\subsection{Self-Confidence}

In the world of work, employees are required to have high work effectiveness. Arif, et al (2019) stated that organizational culture is a pattern of beliefs and organizational values that are believed and imbued by all members in doing work as an appropriate way to understand, think, and feel about related problems, so that it will become a value or rule within the organization. Organizational effectiveness is usually interpreted as the success achieved by an organization in its efforts to achieve predetermined goals (Kuswati, 2019). Employees who work in positions in an organization really need a good sense of selfconfidence. Self-confidence will make employees have the skills to socialize with other employees (Anwar, 2011). Self-confidence can be interpreted as a strong awareness of 
employees about their abilities (Goleman, 2015). Strong self-confidence actually only refers to the existence of several aspects of the individual's life where he feels competent, confident, capable and believes that he can, because it is supported by experience, actual potential, achievements and realistic expectations of himself. For those who lack self-confidence, each failure reinforces their sense of inadequacy. Lack of self-confidence can manifest in the form of hopelessness, feeling of helplessness, and increase self-doubt (Nasution, 2009).

\subsection{Work Stress}

Stress is a dynamic condition in which individuals face opportunities, constraints or demands related to what they really want and the results are perceived as uncertain but important (Robbins, Stephen P; A. Judge, 2012). Furthermore, work stress as a condition of tension that affects a person's thought processes, emotions, and conditions, the result is that too much stress can threaten a person's ability to deal with the environment and will ultimately interfere with the implementation of his duties (Wibowo, 2014). Furthermore, the aspects of work stress include three general categories, namely first, physiological symptoms, that stress can create changes in metabolism, increase heart rate, respiration, cause headaches, and heart attacks. The second is a psychological symptom, that work-related stress can cause job dissatisfaction. The three behavioral symptoms include changes in life habits, anxiety, smoking, excessive appetite, and sleep disturbances (Robbins, Stephen P; A. Judge, 2012).

\subsection{Relationship between Emotional Intelligence on work Stress}

Employees who have a level of emotional intelligence will be able to manage their workload (Rahmat, 2017). The higher the emotional intelligence and self-efficacy together, the lower work stress on employees. Conversely, the lower the emotional intelligence and the efficacy of the employees together, the higher the work stress on employees (Sahrah, 2019). Emotional intelligence is enhanced for decision making by controlling emotions, increasing self-awareness and maintaining other people's relationships and emotional intelligence for employees is the ability to control emotions needed to manage work stress (N. M. A. Y. A. W. G. S. M. S. Putra, 2016). The results of research conducted by (Aprillia, 2019) (Sulindawati, 2017) (Handayani, 2014) shows that emotional intelligence has a negative effect on employee work stress.

\subsection{Relationship between Emotional Intelligence and Work Stress through Self- Confidence}

Having emotional intelligence is not enough to minimize work stress. Employees must also have good self-confidence which is very necessary in employees. The confidence of an employee will be obtained if the employee has sufficient work experience in occupying a position in the organization. The results of research conducted by (N. M. A. Y. A. W. G. S. M. S. Putra, 2016) (Sahrah, 2019) (Handayani, 2014) stated that emotional intelligence has no indirect effect on job stress through employee self-confidence.

Based on the description of the background of the problem and the existing theoretical basis, the conceptual framework in this study is as follows: 


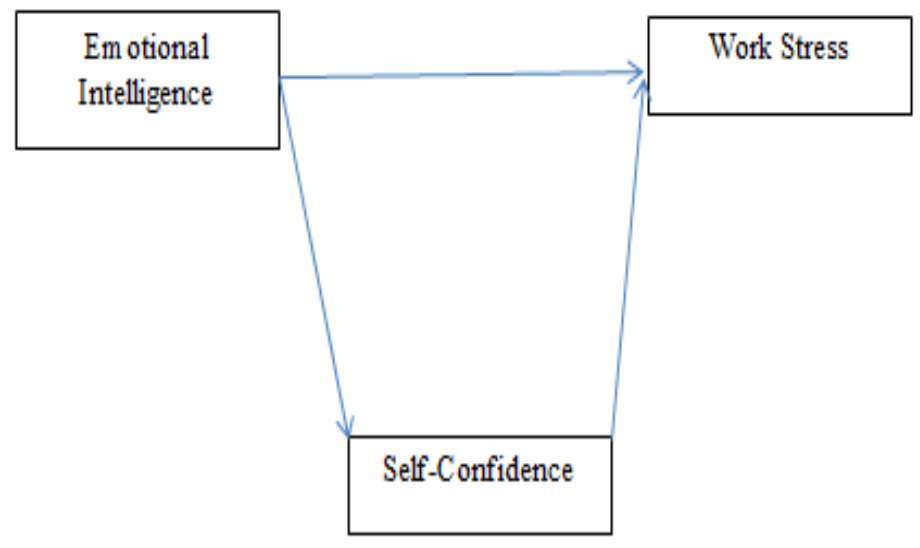

Picture 1 : Theoretical Framework

\section{Research Method}

This research was conducted at PT. Orange Indonesia Mandiri Medan. Where 55 employees were selected to be the object of research in obtaining the necessary data sources. The data collection method used a questionnaire with a Likert scale. Finally, data analysis used path analysis.

\section{Result and Discussion}

\subsection{The Effect of Emotional Intelligence on Work Stress}

It is known that the significance value for the emotional intelligence variable (0.078) is greater than that of 5\% alpha (0.05). Based on the results obtained, Ha refused and accepted. $\mathrm{H} 0$ for emotional intelligence variables. Thus, partially that the emotional intelligence variable does not have a positive and significant effect on work stress. So this research is in accordance with previous research conducted by (N. L. P. N. M. S. Putra, 2015) (Aprillia, 2019) (Rahmat, 2017) which states that emotional intelligence does not have a positive and significant effect on work stress. This means that when emotional intelligence is improved it will reduce work stress.

\subsection{The Effect of Emotional Intelligence on Work Stress through Self - Confidence}

The results of this study indicate that:

a. The direct effect of emotional intelligence on work stress is by looking at the regression coefficient value of $\mathrm{P} 2$ of 0.315

b. The indirect effect of emotional intelligence on work stress through self-confidence is seen from the multiplication of the regression coefficient of emotional intelligence on selfconfidence with the regression coefficient value for self-confidence on work stress, namely $\mathrm{P} 1 \mathrm{xP} 3=0.426 \times 0.352=0.149$

c. So it can be concluded that the value of the indirect effect coefficient is P1xP3> P2 (0.149 $<0.315)$. This means that self-confidence has an indirect effect on work stress.

From the results of the above research, this research is in accordance with the results of previous research conducted by (N. M. A. Y. A. W. G. S. M. S. Putra, 2016) (Sahrah, 2019) (Handayani, 2014) which states that emotional intelligence does not have a positive and significant effect on work stress through self-confidence. This shows that when employees increase their confidence, it will have an impact on reducing the work stress they face. 


\section{Conclusion}

Based on the results of research and discussion, the conclusion in this study is that emotional intelligence has no positive and significant effect on work stress and emotional intelligence does not have a positive and significant effect on work stress through selfconfidence. This means that when emotional intelligence and self-confidence are getting better, it will reduce employee work stress.

The suggestion in this study is emotional intelligence, namely by continuing to provide understanding to other employees to continue learning from employees who have good emotional intelligence. Furthermore, the leadership also has an important role in providing motivation to every employee to continue learning to face every problem that exists from employees who have experience.

\section{References}

Anwar, Y. (2011). Pengaruh Kecerdsan Emosional Dan Kepercayaan Diri Terhadap Personal Value Serta Dampaknya Terhadap Pemahaman Akuntansi Keuangan. Media Riset Akuntansi, Auditing \& Informasi, 11(2), 89-122.

Aprillia, F. L. I. F. (2019). Pengaruh Kecerdasan Emosi Terhadap Stres Kerja Pada Pengajar Muda Di Gerakan Indonesia Mengajar. JPPP - Jurnal Penelitian Dan Pengukuran Psikologi, 8(1), 1-11. https://doi.org/10.21009/jppp.081.01

Arif, S., Zainuddin and K. Hamid, A. (2019). Influence of Leadership, Organizational Culture, Work Motivation, and Job Satisfaction of Performance Principles of Senior High School in Medan City. Budapest International Research and Critics InstituteJournal (BIRCI-Journal), P. 239-254.

Chaniago, N. S. (2018). Pengaruh Lingkungan Kerja Dan Insentif Terhadap Kinerja Pegawai Pada PT. Pegadaian (Persero) Cabang Labuhan Deli. Bisman Info, 5(2), 736-755.

Fajrin, I. Q. H. S. (2018). Pengaruh Gaya Kepemimpinan Terhadap Kinerja Karyawan Dengan Motivaso Sebagai Variabel Intervening (Studi pada Karyawan Pabrik Gula Kebon Agung Malang). Jurnal Administrasi Bisnis (JAB), 61(4), 117-124.

Goleman, D. (2015). Emotional Intelligence: Kecerdasan emosional mengapa EI lebih penting daripada IQ. Jakarta: PT. Gramedia Pustaka Utama.

Handayani, P. G. W. I. I. D. (2014). Pengaruh Kecerdasan Emosional, Perilaku Belajar dan Budaya terhadap Tingkat Pemahaman Akuntansi dengan Kepercayaan Diri sebagai Variabel Moderating (Studi Empiris pada Mahasiswa di Perguruan Tinggi Swasta Kota Madiun). Jurnal Riset Manajemen Dan Akuntansi, 2(1), 25-34. Retrieved from http://portal.widyamandala.ac.id/jurnal/index.php/jrma/article/view/196

Kuswati, Y. (2019). Motivation Role in Improving Work Effectiveness. Budapest International Research and Critics Institute-Journal (BIRCI-Journal), P. 281-288.

Martin. (2020). Job Satisfaction Optimization by Work Atmosphere, Stress of Work, and Work Motivation. International Journal of Innovative Science and Research Technology, 5(5), 110-113.

Nasution, F. A. (2009). Pengaruh Kecerdasan Emosional Dan Kepercayaan Diri Terhadap Tingkat Pemahaman Akuntansi Mahasiswa UMSU. Riset Akuntansi Dan Bisnis, 9(2), $111-122$.

Ningsih, S. (2018). The Relationship between Motivation and Worker's Productivity in Civil Registration and Population Department, Asahan Regency, Indonesia. Budapest International Research and Critics Institute-Journal (BIRCI-Journal), P. 148-160. 
Putra, N. L. P. N. M. S. (2015). Pengaruh Kecerdasan Emosional Terhadap Kepuasan Kerja Dan Stres Kerja Pada the Seminyak Beach Resort and Spa. E-Jurnal Manajemen Unud, 4(10), 2302-8912.

Putra, N. M. A. Y. A. W. G. S. M. S. (2016). Pengaruh Kecerdasan Emosional Terhadap Stres Kerja Dan Kepuasan Kerja Pada Karyawan Pdam Tirta Mangutama Kabupaten Badung. E-Jurnal Ekonomi Dan Bisnis Universitas Udayana, 5(7), 2231-2260.

Rahmat, A. (2017). Kecerdasan Emosional Dan Dampaknya Terhadap Stres Kerja Dan Kinerja Karyawan. Jurnal Ekonomi Dan Bisnis Islam UIN Imam Bonjol, 2(1), 43-57. https://doi.org/10.17605/OSF.IO/HN423

Rivai, V. (2014). Manajemen Sumber Daya Manusia Untuk Perusahaan, Dari Teori ke Praktik. Jakarta: PT. Raja Grafindo Persada.

Robbins, Stephen P; A. Judge, T. (2012). Perilaku organisasi. (Salemba Empat, Ed.). Jakarta.

Sahrah, W. S. A. (2019). Pengaruh Kecerdasan Emosi Dan Efikasi Diri Terhadap Stres Kerja Pada Karyawan NU Imej Agency And Event Organizer Yogyakarta. In Prosiding Seminar Nasional Pakar (pp. 1-6).

Sulindawati, P. E. S. N. T. H. L. G. E. (2017). Pengaruh Kecerdasan Emosional Dan Minat Belajar Terhadap Tingkat Pemahaman Akuntansi Dengan Kepercayaan Diri Sebagai Variabel Pemoderasi (Studi Kasus Pada Mahasiswa S1 Akuntansi Universitas Pendidikan Ganesha). JIMAT (Jurnal Ilmiah Mahasiswa Akuntansi S1), 7(1), 1-13. https://doi.org/10.23887/jimat.v7i1.10134

Wibowo. (2014). Manajemen Kinerja; Cetakan Keempat. Jakarta: PT. Raja Grafindo Persada. 